ISSN 0258-7122 (Print), 2408-8293 (Online)

Bangladesh J. Agril. Res. 44(3): 427-437, September 2019

\title{
INTEGRATED MANAGEMENT OF BACTERIAL WILT AND ROOT KNOT NEMATODE OF BRINJAL
}

\author{
M. I. FARUK ${ }^{1}$, M. M. ISLAM ${ }^{2}$, F. KHATUN ${ }^{3}$ \\ M. A. HOSSAIN ${ }^{4}$ AND T. K. DEY ${ }^{5}$
}

\begin{abstract}
The field experiment was conducted at Regional Agricultural Research Station (RARS), Hathazari, Chattagram to find out the efficacy of integration of poultry refuse (PR) with stable bleaching powder (SBP) or $\mathrm{CaNO}_{3}$ and Furadan 5G for the management of bacterial wilt (Ralstonia solanacearum) and root-knot nematode disease (Meloidogyne incognita) of brinjal. Soil was treated with PR @ 3 t/ha 3 weeks before transplanting, stable bleaching powder @ $20 \mathrm{~kg} / \mathrm{ha}$ during final land preparation and Furadan $5 \mathrm{G} @ 20 \mathrm{~kg} / \mathrm{ha}$ on the day of seedlings transplanting while $\mathrm{CaNO}_{3}$ was used as soil drenching 10 days after seedling transplanting. Results showed that integration of poultry refuse with Furadan $5 \mathrm{G}$ and stable bleaching powder or $\mathrm{CaNO}_{3}$ reduced root-knot and bacterial wilt diseases and increased plant growth as well as yield of brinjal. The most effective treatment combination was $\mathrm{PR}+$ stable bleaching powder + Furadan $5 \mathrm{G}$ with early sowing, followed by $\mathrm{PR}+\mathrm{CaNO}_{3}+$ Furadan $5 \mathrm{G}$ with early sowing for the management of bacterial wilt and root knot nematode diseases and increasing plant growth and yield of brinjal. The technology, poultry refuse+ stable bleaching powder + Furadan $5 \mathrm{G}$ was validated at Bangladesh Agricultural Research Institute (BARI), Gazipur, Regional Agricultural Research Station of Jessore, Hathazari and Jamalpur and also at Agricultural Research Station and farmers field at Burirhat, Rangpur and OFRD farm at Alamnagar, Rangpur. The validation trials showed that integration of poultry refuse + stable bleaching powder+ Furadan $5 \mathrm{G}$ in early sowing was an effective management package of bacterial wilt and root knot nematode diseases of brinjal which also offered 21.81 to $25.98 \%$ higher yield over the conventional practices.
\end{abstract}

Keywords: Poultry refuse, Stable bleaching powder, Furadan, $\mathrm{CaNO}_{3}$, Meloidogyne incognita, Ralstonia solanacearum and Brinjal.

\section{Introduction}

Availability of quality food and nutrition are the major challenges to achieve healthy and prosperous Bangladesh like other developing countries of the world. Vegetable play a vital role in everyday diet in general and it is an important source of vitamins, minerals and plant proteins in human diets throughout the

\footnotetext{
${ }^{1 \& 2}$ Senior Scientific Officer, Plant Pathology Division, Bangladesh Agricultural Research Institute (BARI), Gazipur, ${ }^{3}$ Chief Scientific Officer and Head, Plant Pathology Division, BARI, Gazipur, ${ }^{4}$ Chief Scientific Officer and Head, Soil Science Division, BARI, Gazipur, ${ }^{5}$ Ex-Director, Pulse Research Center, BARI, Gazipur, Bangladesh.
} 
world. Among the vegetables, brinjal (eggplant) (Solanum melongena L.) is the second most important vegetable crop next to potato in Bangladesh in respect of acreage and production (BBS, 2005). It is cultivated commercially throughout the tropical and subtropical region of the world under field and greenhouse conditions. It is also popular in other countries like Balkan area, France, Indonesia, Italy, Japan, Mediterranean, Turkey and United states (Bose and Som, 1986). But the productivity of brinjal in Bangladesh is low (17.5 t/ha) as compared to Japan (32 t/ha), Italy (28.2 t/ha) and Turkey (30.2 t//ha) FAOSTAT (2012). It is estimated that $10 \%$ of crops are lost due to plant diseases worldwide each year which can lead to considerable financial losses for the farmers of underdeveloped countries (Strange and Scott 2005). This crop suffers from the various diseases; about 13 different diseases so far recorded in Bangladesh (Das et al., 2000; Khan et al., 1998; Rashid, 2000). Among the diseases wilt of eggplant especially Bacterial wilt caused by Ralstonia solnacearum is damaging for solanaceous crops worldwide (Ali, 1993; Hayward, 2005). In Bangladesh brinjal and tomato are seriously affected by bacterial wilt (Rahman and Haque, 1986; Rahman et al., 2010). Another devastating disease for brinjal root-knot disease caused by Meloidogyne spp. is highly damaging and yield reducing factor throughout the country (Mian, 1986). A number of approaches for controlling bacterial wilt and root-knot nematodes including development of resistant variety have been taken, but the success is very few. For management of bacterial wilt disease e.g. intercropping, crop rotation and soil amendment against the pathogen has been reported (Sood et al., 1998; Yadessa et al., 2010; Djeugap et al., 2014). In case of root-knot nematodes application of nematicide, (Hossain et al., 1989), organic soil amendments (Faruk et al., 2001; Bari et al., 2004; Hassan et. al., 2010, Zakaria et al. 2013), cultural management, physical methods like crop rotation and biological measures like Trichoderma spp, Pacecilomyces lilacinus, Pasturia penetrans, Verticillium chlamydosporium and Pseudomonas aeruginosa (Viaene and Abawi, 2000; Moraes et al., 2006; Santana et al., 2012; Zakaria et al., 2013; Lamovšek et al., 2013) are being used. Presently, researchers have been diverted their attention to develop integrated approaches against the pest because often any single approach is insufficient to manage bacterial wilt and root knot nematode diseases of brinjal efficiently. Under the above circumstances, the study was undertaken to find out efficacy of poultry refuses, stable bleaching powder, $\mathrm{CaNO}_{3}$ and Furadan $5 \mathrm{G}$ to manage bacterial wilt and root-knot nematode of brinjal and to increase plant growth and yield of brinjal.

\section{Materials and Methods}

Field experiment: The experiment was conducted at the Regional Agricultural Research Station, Hathazari, Chattagram during 2011-12 to find out the effective management practices against bacterial wilt and root-knot nematode disease of brinjal. The unit plot size was $3 \mathrm{~m} \times 3.75 \mathrm{~m}$ keeping $1 \mathrm{~m}$ distance from plot to plot. The experiment was laid out in a randomized complete block design 
with three replications. Thirty days old brinjal seedlings var. BARI Begun-4 was cultivated. Ten treatments viz., $\mathrm{T}_{1}=$ Poultry refuse @ $3 \mathrm{t} / \mathrm{h}+$ Stable bleaching powder@20 kg/h + early sowing (Middle of October), $\mathrm{T}_{2}=$ Poultry refuse@ 3 $\mathrm{t} / \mathrm{h}+\mathrm{CaNO}_{3} @ 1 \%$ solution + early sowing, $\mathrm{T}_{3}=$ Poultry refuse@ $3 \mathrm{t} / \mathrm{h}+$ Stable bleaching powder@20 kg/h + Furadan5G@20 kg/h + early sowing, $\mathrm{T}_{4}=$ Poultry refuse@3 t/h + $\mathrm{CaNO}_{3} @ 1 \%$ solution+Furadan5G@20 kg/h + early sowing, $\mathrm{T}_{5}=$ Control-1 (as comparison for early sowing) $\mathrm{T}_{6}=$ Poultry refuse @ 3 $\mathrm{t} / \mathrm{h}+$ Stable bleaching powder @ $20 \mathrm{~kg} / \mathrm{h}+$ late sowing $\left(1^{\text {st }}\right.$ week of December $)$, $\mathrm{T}_{7}=$ Poultry refuse@ $3 \mathrm{t} / \mathrm{h}+\mathrm{CaNO}_{3} @ 1 \%$ solution + late sowing, $\mathrm{T}_{8}=$ Poultry refuse@3 t/h + Stable bleaching powder@20 kg/h + Furadan 5G@20 kg/h + late sowing, $\mathrm{T}_{9}=$ Poultry refuse@3 t/h $+\mathrm{CaNO}_{3} @ 1 \%$ solution+Furadan5G@ $20 \mathrm{~kg} / \mathrm{h}+$ late sowing and $\mathrm{T}_{10}=$ Control-2 (as comparison for late sowing). Partially decomposed poultry refuse @ $3 \mathrm{t} / \mathrm{h}$ was added to the soil three weeks before seedling transplanting for proper decomposition. Furadan 5G was added before seedling transplanting, Stable bleaching powder was used during final land preparation and $\mathrm{CaNO}_{3}$ was used as soil drenching after 10 days ages of the plant. Recommended fertilizers (Urea $300 \mathrm{~kg} / \mathrm{ha}$, TSP $250 \mathrm{~kg} / \mathrm{ha}$, MP $200 \mathrm{~kg} / \mathrm{ha}$ and Zypsum $100 \mathrm{~kg} / \mathrm{ha}$ ) were added during final land preparation as well as split at three times of different crop growth stages, weeding and irrigation were done as per recommendation of the crop.

\section{Validation of developed technology}

The validation trials using BARI Begun- 8 for controlling bacterial wilt and root knot nematode diseases were conducted in the field of Plant Pathology Division, Bangladesh Agricultural Research Institute (BARI), Gazipur and also in the Regional Agricultural Research Station (RARS), Hathazari and Jamalpur during 2012-13 cropping season. The developed technology that is poultry refuse @ 3 $\mathrm{t} / \mathrm{ha}+$ Stable bleaching powder @ $20 \mathrm{~kg} / \mathrm{h}+$ Furadan $5 \mathrm{G} 25 \mathrm{~kg} / \mathrm{ha}$ for integrated management of root knot nematode and bacterial wilt of brinjal was applied in the locations of Gazipur, Jamalpur and Hathazari where control treatment was also used for comparison. The unit plot size was approximately 1500 square meter and spacing was $60 \mathrm{~cm} \times 60 \mathrm{~cm}$. Similar trials with BARI Begun-4 and BARI Begun-10 were also conducted at the Regional Agricultural Research Station (RARS), Jessore and Burirhat, Rangpur, farmers' field at Burirhat, Rangpur and OFRD farm at Alamnagar, Rangpur during 2012-13 cropping season where no control treatment was used. Poultry refuse was applied @ 5t/ha before 21 days of seedling transplanting. After application poultry refuse was properly mixed with soil and water was added frequently for complete decomposition of poultry refuse in the soil. Stable bleaching powder @ $20 \mathrm{~kg} / \mathrm{h}$ was applied at the final stage of land preparation and Furadan 5G was mixed at the time of seedling transplanting. Brinjal seedlings were transplanted at the age of 35-40 days. Intercultural operations were done as per standard recommendation. 
Data collection and analysis: Data on different parameters viz. shoot height, shoot weight, root length, root weight and yield of brinjal were taken. During the growing period bacterial wilt incidence was recorded from seedling to maturity stage of the crop. Root knot disease severity was recorded as a gall index following 0-10 scale (Zeck, 1971) after final harvesting of brinjal. The percent data were converted into arcsine transformation values before statistical analysis. Data were analyzed statistically by using the MSTAT-C program. The treatment effects were compared by applying the least significant different (LSD) test at $\mathrm{P}=0.05$ level.

\section{Results and Discussion}

Shoot growth: Average shoot length of brinjal was significantly increased in case of various treatments and it was comparatively low in control-1 and control2 (22.33 and $20.00 \mathrm{~cm} \mathrm{plant}^{-1}$, respectively) while integrated soil amendments with poultry refuse (PR), stable bleaching powder (SBP), $\mathrm{CaNO}_{3}$ and Furadan $5 \mathrm{G}$ showed increased shoot length both in early sowing (ES) and late sowing (LS) condition ranging from 27.52-42.61 $\mathrm{cmplant}^{-1}$ and $23.00-37.25 \mathrm{~cm}^{-1 a n t^{-1}}$, respectively (Table 1). The highest shoot length $\left(42.61 \mathrm{~cm} \mathrm{plant}^{-1}\right)$ was obtained with integration of $\mathrm{PR}+\mathrm{SBP}+$ Furadan $5 \mathrm{G}+\mathrm{ES}$ followed by the treatments $\mathrm{PR}$ + SBP + Furadan 5G +LS $\left(38.53 \mathrm{~cm} \mathrm{plant}^{-1}\right), \mathrm{PR}+\mathrm{CaNO}_{3}+$ Furadan $5 \mathrm{G}+$ $\mathrm{ES}\left(37.69 \mathrm{~cm}\right.$ plant $\left.{ }^{-1}\right)$. The treatments $\mathrm{PR}+\mathrm{SBP}+\mathrm{ES}, \mathrm{PR}+\mathrm{CaNO}_{3}+\mathrm{ES}$ and $\mathrm{PR}+$ $\mathrm{CaNO}_{3}+$ Furadan $5 \mathrm{G}+\mathrm{LS}$ produced comparatively short shoot length. The least effective treatments to increase shoot length was $\mathrm{PR}+\mathrm{CaNO}_{3}+\mathrm{LS}$ and $\mathrm{PR}+$ SBP+ LS (23.00 cm plant $\left.{ }^{-1}\right)$.

The shoot weight of brinjal was 140.70 and $130.0 \mathrm{~g} \mathrm{plant}^{-1}$ in control-1 and control-2, respectively. Integration of PR, SBP, $\mathrm{CaNO}_{3}$ and Furadan5G increased shoot weight by $142.50-167.00 \mathrm{~g} \mathrm{plant}^{-1}$ at early sowing and $141.7-164.6 \mathrm{~g} \mathrm{plant}^{-1}$ at late sowing conditions. The highest shoot weight was achieved by the treatment of PR $+\mathrm{SBP}+$ Furadan $5 \mathrm{G}+\mathrm{ES}$ followed by $\mathrm{PR}+\mathrm{SBP}+$ Furadan $5 \mathrm{G}+\mathrm{LS}, \mathrm{PR}+\mathrm{SBP}+\mathrm{ES}, \mathrm{PR}+\mathrm{CaNO}_{3}+$ Furadan $5 \mathrm{G}+\mathrm{ES}$ and $\mathrm{PR}+\mathrm{CaNO}_{3}+\mathrm{LS}$. The least effective treatment to increase shoot weight was $\mathrm{PR}+\mathrm{CaNO}_{3}+$ Furadan $5 \mathrm{G}+\mathrm{LS}$ followed by $\mathrm{PR}+\mathrm{CaNO}_{3}+\mathrm{ES}$ and $\mathrm{PR}+\mathrm{CaNO}_{3}+\mathrm{LS}$ which were statistically similar to control treatments (Table 1 ).

Root growth: Soil amended with PR, SBP and $\mathrm{CaNO}_{3}$ and application of Furadan 5G showed positive effects on root growth of brinjal as compared to untreated control. Minimum root length $\left(8.60 \mathrm{~cm} \mathrm{plant}^{-1}\right)$ was recorded in control-2 (Table 1). The highest root length $\left(28.64 \mathrm{~cm} \mathrm{plant}^{-1}\right)$ was recorded in $\mathrm{PR}+\mathrm{SBP}+$ Furadan $5 \mathrm{G}+\mathrm{ES}$ treatment which was followed by $\mathrm{PR}+\mathrm{CaNO}_{3}+$ Furadan $5 \mathrm{G}+\mathrm{ES}, \mathrm{PR}+\mathrm{SBP}+$ Furadan $5 \mathrm{G}+\mathrm{LS}$ and $\mathrm{PR}+\mathrm{SBP}+\mathrm{ES}$. The rest of the treatments was least effective to increase root length (Table 1). Root weight was $5.18 \mathrm{~g}$ plant $^{-1}$ and $7.67 \mathrm{~g}$ plant $^{-1}$ in control-2 and control-1, respectively. The highest root weight $\left(22.58 \mathrm{~g} \mathrm{plant}^{-1}\right)$ was recorded in integration of PR + SBP + 
Furadan $5 \mathrm{G}+\mathrm{ES}$, which was followed by $\mathrm{PR}+\mathrm{CaNO}_{3}+$ Furadan $5 \mathrm{G}+\mathrm{ES}, \mathrm{PR}+$ $\mathrm{SBP}+$ Furadan $5 \mathrm{G}+\mathrm{LS}$ and $\mathrm{PR}+\mathrm{SBP}+\mathrm{ES}$. The rest of the treatment was found least effective to increase root weight.

Table 1. Effect of integrated management approaches on vegetative growth of brinjal

\begin{tabular}{|c|c|c|c|c|}
\hline Treatment & $\begin{array}{c}\text { Shoot } \\
\text { Length }(\mathbf{c m})\end{array}$ & $\begin{array}{c}\text { Shoot } \\
\text { Weight (gm) }\end{array}$ & $\begin{array}{l}\text { Root Length } \\
\text { (cm) }\end{array}$ & $\begin{array}{c}\text { Root } \\
\text { Weight } \\
(\text { gm) }\end{array}$ \\
\hline $\mathrm{PR}+\mathrm{SBP}+\mathrm{ES}$ & $37.25 \mathrm{~b}$ & $164.2 \mathrm{ab}$ & $21.04 \mathrm{~b}$ & $19.43 \mathrm{~b}$ \\
\hline $\mathrm{PR}+\mathrm{CaNO}_{3}+\mathrm{ES}$ & $27.52 \mathrm{c}$ & $142.5 \mathrm{e}$ & $13.47 \mathrm{c}$ & $11.11 \mathrm{c}$ \\
\hline $\mathrm{PR}+\mathrm{SBP}+$ Furadan+ES & $42.61 \mathrm{a}$ & $167.0 \mathrm{a}$ & $28.64 \mathrm{a}$ & $22.58 \mathrm{a}$ \\
\hline $\mathrm{PR}+\mathrm{CaNO}_{3}+$ Furadan+ES & $37.69 \mathrm{~b}$ & $161.0 \mathrm{bc}$ & $23.64 \mathrm{~b}$ & $21.85 \mathrm{ab}$ \\
\hline Control-1 & $22.33 \mathrm{~d}$ & $140.7 \mathrm{e}$ & $12.43 \mathrm{c}$ & $7.67 \mathrm{de}$ \\
\hline $\mathrm{PR}+\mathrm{SBP}+\mathrm{LS}$ & $23.00 \mathrm{~d}$ & $152.0 \mathrm{~d}$ & $14.33 \mathrm{c}$ & $8.17 \mathrm{~d}$ \\
\hline $\mathrm{PR}+\mathrm{CaNO}_{3}+\mathrm{LS}$ & $23.20 \mathrm{~d}$ & $156.0 \mathrm{~cd}$ & $13.00 \mathrm{c}$ & $9.67 \mathrm{~cd}$ \\
\hline PR+SBP+Furadan+LS & $38.53 \mathrm{~b}$ & $164.6 \mathrm{ab}$ & $21.58 \mathrm{~b}$ & $20.17 \mathrm{ab}$ \\
\hline $\mathrm{PR}+\mathrm{CaNO}_{3}+$ Furadan $+\mathrm{LS}$ & $27.20 \mathrm{c}$ & $141.7 \mathrm{e}$ & $14.73 \mathrm{c}$ & $12.27 \mathrm{c}$ \\
\hline Control-2 & $20.00 \mathrm{~d}$ & $130.0 \mathrm{f}$ & $8.60 \mathrm{~d}$ & $5.18 \mathrm{e}$ \\
\hline
\end{tabular}

Values within the same column with a common letter do not differ significantly $(\mathrm{P}=0.05)$ by LSD test.

$\mathrm{PR}=$ Poultry refuse, $\mathrm{SBP}=$ Stable bleaching powder, ES=Early sowing (Middle of October), LS= Late sowing ( $1^{\text {st }}$ week of December)

Severity of bacterial wilt and root knot nematode: The severity of root knot disease and bacterial wilt of brinjal was significantly reduced compared to control due to integration of PR, SBP, $\mathrm{CaNO}_{3}$ and Furadan $5 \mathrm{G}$ for soil treatment (Table 2). Higher bacterial wilt $(22.67 \%$ and $20.80 \%)$ incidence was recorded from control-2 and control-1 plots, respectively. Integration of different treatments reduced bacterial wilt incidence by 38.46-61.54\% at early sowing and $32.95-64.71 \%$ at late sowing conditions as compared to control. Regarding the root knot nematode disease, average gall index value of 4.34 and 5.12 was recorded in the control-2 and control-1 plots, respectively. The gall index value under integration of different treatments with PR, SBP, $\mathrm{CaNO}_{3}$ and Furadan 5G range from 1.63-2.52 at early sowing and 1.83-2.86 at late sowing conditions. Maximum reduction of gall index value $(68.16 \%)$ was obtained with PR +SBP + Furadan $5 \mathrm{G}+\mathrm{ES}$ compared to control followed by PR + SBP + Furadan $5 \mathrm{G}+\mathrm{LS}$ $(56.25 \%), \mathrm{PR}+\mathrm{CaNO}_{3}+$ Furadan $5 \mathrm{G}+\mathrm{ES}(51.95 \%), \mathrm{PR}+\mathrm{SBP}+\mathrm{ES}, \mathrm{PR}+$ $\mathrm{CaNO}_{3}++\mathrm{ES}(50.78 \%)$ and $\mathrm{PR}+\mathrm{CaNO}_{3}+$ Furadan $5 \mathrm{G}+\mathrm{LS}(50.69 \%)$.

Crop yield: Integration of organic soil amendments with $\mathrm{PR}, \mathrm{SBP}, \mathrm{CaNO}_{3}$ and Furadan 5G gave significant increase in fruit number/plant, fruits weight/plant and fruit yield per hectare (Table 3). Fruit number per plant was 9.00 and 11.00 under control-2 and control-1, respectively. Fruits yield was increased by 24.00 to 28.33 per plant at early sowing and 20.00 to 24.67 per plant at late sowing in different treatments. Fruits weight per plant $0.64 \mathrm{~g} / \mathrm{plant}$ and $0.84 \mathrm{~g} / \mathrm{plant}$ under 
control-2 and control-1 treatments, respectively. The highest fruits weight 1.73 $\mathrm{kg}$ plant $^{-1}$ was achieve by $\mathrm{PR}+\mathrm{SBP}+$ Furadan $5 \mathrm{G}+\mathrm{ES}$ followed by and $\mathrm{PR}+$ $\mathrm{CaNO}_{3}+$ Furadan $5 \mathrm{G}+\mathrm{ES}, \quad \mathrm{PR}+\mathrm{SBP}+$ Furadan $5 \mathrm{G}+\mathrm{LS}$ and $\mathrm{PR}+\mathrm{SBP}+\mathrm{ES}$ treatments.

Table 2. Effect of integrated management approaches on bacterial wilt and root knot diseases of tomato

\begin{tabular}{|c|c|c|c|c|}
\hline Treatments & $\begin{array}{l}\text { Bacterial } \\
\text { wilt } \\
\text { incidence } \\
(\%)\end{array}$ & $\begin{array}{c}\text { Reduction of } \\
\text { Bacterial wilt } \\
\text { incidence over } \\
\text { control }(\%) \\
\end{array}$ & $\begin{array}{l}\text { Gall index } \\
(0-10 \text { scale })\end{array}$ & $\begin{array}{c}\text { Reduction of } \\
\text { gall index value } \\
\text { over control }(\%)\end{array}$ \\
\hline $\mathrm{PR}+\mathrm{SBP}+\mathrm{ES}$ & $11.20 \mathrm{de}$ & 46.15 & $2.46 \mathrm{~d}$ & 51.95 \\
\hline $\mathrm{PR}+\mathrm{CaNO}_{3}+\mathrm{ES}$ & $12.80 \mathrm{~cd}$ & 38.46 & $2.52 \mathrm{~d}$ & 50.78 \\
\hline PR+SBP+Furadan+ES & $8.00 \mathrm{f}$ & 61.54 & $1.63 \mathrm{~g}$ & 68.16 \\
\hline $\begin{array}{ll}\mathrm{PR}+ & \mathrm{CaNO}_{3} \\
+ \text { Furadan+ES } & \end{array}$ & $9.60 \mathrm{ef}$ & 53.85 & $2.24 \mathrm{e}$ & 56.25 \\
\hline Control-1 & $20.80 \mathrm{a}$ & - & $5.12 \mathrm{a}$ & - \\
\hline PR+SBP+LS & $14.40 \mathrm{bc}$ & 36.48 & $2.18 \mathrm{e}$ & 49.77 \\
\hline $\mathrm{PR}+\mathrm{CaNO}_{3}+\mathrm{LS}$ & $15.20 \mathrm{~b}$ & 32.95 & $2.14 \mathrm{e}$ & 34.10 \\
\hline $\mathrm{PR}+\mathrm{SBP}+$ Furadan+LS & $8.00 \mathrm{f}$ & 64.71 & $1.83 \mathrm{f}$ & 57.83 \\
\hline $\begin{array}{ll}\mathrm{PR}+ & \mathrm{CaNO}_{3} \\
+ \text { Furadan+ES } & \end{array}$ & $12.27 \mathrm{~d}$ & 45.88 & $2.86 \mathrm{c}$ & 50.69 \\
\hline Control-2 & $22.67 \mathrm{a}$ & - & $4.34 \mathrm{~b}$ & - \\
\hline
\end{tabular}

Values within the same column with a common letter do not differ significantly $(\mathrm{P}=0.05)$ by LSD test.

$\mathrm{PR}=$ Poultry refuse, $\mathrm{SBP}=$ Stable bleaching powder, ES=Early sowing, $\mathrm{LS}=$ Late sowing

Table 3. Effect of integrated management approaches on the yield of brinjal

\begin{tabular}{|c|c|c|c|c|}
\hline Treatment & $\begin{array}{l}\text { No. of fruits/ } \\
\text { plant }\end{array}$ & $\begin{array}{l}\text { Weight of } \\
\text { fruits/plant } \\
(\mathrm{Kg})\end{array}$ & $\begin{array}{l}\text { Yield } \\
(\mathrm{t} / \mathrm{ha})\end{array}$ & $\begin{array}{c}\text { Yield increased } \\
\text { over control } \\
(\%) \\
\end{array}$ \\
\hline $\mathrm{PR}+\mathrm{SBP}+\mathrm{ES}$ & $24.00 \mathrm{bc}$ & $1.54 \mathrm{abc}$ & $22.51 \mathrm{~b}$ & 43.27 \\
\hline $\mathrm{PR}+\mathrm{CaNO}_{3}+\mathrm{ES}$ & $25.67 \mathrm{ab}$ & $1.38 \mathrm{~cd}$ & $21.59 \mathrm{bc}$ & 40.85 \\
\hline $\mathrm{PR}+\mathrm{SBP}+$ Furadan+ES & $28.33 \mathrm{a}$ & $1.73 \mathrm{a}$ & $24.73 \mathrm{a}$ & 48.36 \\
\hline $\mathrm{PR}+\mathrm{CaNO}_{3}+$ Furadan+ES & $26.00 \mathrm{ab}$ & $1.64 \mathrm{ab}$ & $24.56 \mathrm{a}$ & 48.00 \\
\hline Control-1 & $11.00 \mathrm{e}$ & $0.84 \mathrm{f}$ & $12.77 \mathrm{~d}$ & - \\
\hline $\mathrm{PR}+\mathrm{SBP}+\mathrm{LS}$ & $20.00 \mathrm{~d}$ & $1.15 \mathrm{e}$ & $20.56 \mathrm{c}$ & 42.36 \\
\hline $\mathrm{PR}+\mathrm{CaNO}_{3}+\mathrm{LS}$ & $21.67 \mathrm{~cd}$ & $1.32 \mathrm{de}$ & $22.23 b$ & 46.69 \\
\hline PR+SBP+Furadan+LS & $23.33 \mathrm{bcd}$ & $1.59 \mathrm{ab}$ & $22.32 \mathrm{~b}$ & 46.91 \\
\hline $\mathrm{PR}+\mathrm{CaNO}_{3}+$ Furadan+ES & $24.67 \mathrm{abc}$ & $1.48 \mathrm{bcd}$ & $22.37 \mathrm{~b}$ & 47.03 \\
\hline Control-2 & $9.00 \mathrm{e}$ & $0.64 \mathrm{~g}$ & $11.85 \mathrm{~d}$ & - \\
\hline
\end{tabular}

Values within the same column with a common letter do not differ significantly $(\mathrm{P}=0.05)$ by LSD test.

$\mathrm{PR}=$ Poultry refuse, $\mathrm{SBP}=$ Stable bleaching powder, $\mathrm{ES}=$ Early sowing, $\mathrm{LS}=$ Late sowing. 
The lower yields 11.85 and $12.77 \mathrm{t} /$ ha were found in control-2 and control-1 treatments, respectively. Application of different treatments increased the fruit yield upto 21.59-24.73 $\mathrm{t} \mathrm{ha}^{1}$ at early sowing and 20.56-22.37 $\mathrm{t} \mathrm{ha}^{-1}$ at late sowing conditions. Integration of PR +SBP + Furadan $5 \mathrm{G}+\mathrm{ES}$ gave significantly higher (48.36\%) yield compared to control followed by $\mathrm{PR}+\mathrm{CaNO}_{3}+$ Furadan $5 \mathrm{G}+\mathrm{ES}$ (48.00\%), PR $+\mathrm{CaNO}_{3}+$ Furadan $5 \mathrm{G}+\mathrm{LS}(47.03 \%), \mathrm{PR}+\mathrm{SBP}+$ Furadan $5 \mathrm{G}+\mathrm{LS}(46.91 \%)$ and $\mathrm{PR}+\mathrm{CaNO}_{3}+\mathrm{LS}(46.69 \%)$, respectively.

Table 4. Validation of integrated management of bacterial wilt and root knot nematode of brinjal at Gazipur, Hathazari and Jamalpur

\begin{tabular}{|c|c|c|c|c|c|c|}
\hline \multirow[b]{2}{*}{ Location } & \multirow[b]{2}{*}{ Variety } & \multirow[b]{2}{*}{ Treatment } & \multicolumn{2}{|c|}{ Disease incidence } & \multirow[b]{2}{*}{$\begin{array}{l}\text { Yield } \\
(\mathrm{t} / \mathrm{ha})\end{array}$} & \multirow{2}{*}{$\begin{array}{c}\text { Yield } \\
\text { higher } \\
\text { over } \\
\text { control } \\
(\%)\end{array}$} \\
\hline & & & $\begin{array}{c}\text { Bacterial wilt } \\
(\%)\end{array}$ & $\begin{array}{c}\text { Root } \\
\text { knot }(0- \\
10 \text { scale })\end{array}$ & & \\
\hline \multirow{2}{*}{$\begin{array}{l}\text { BARI, } \\
\text { Gazipur }\end{array}$} & \multirow{2}{*}{$\begin{array}{c}\text { BARI } \\
\text { Begun-8 }\end{array}$} & Treated & 0.88 & 1.50 & 44.50 & 25.62 \\
\hline & & Control & 7.50 & 2.75 & 33.10 & - \\
\hline \multirow{2}{*}{$\begin{array}{l}\text { RARS, } \\
\text { Hathazari }\end{array}$} & \multirow{2}{*}{$\begin{array}{c}\text { BARI } \\
\text { Begun-8 }\end{array}$} & Treated & 4.50 & 1.40 & 43.50 & 25.98 \\
\hline & & Control & 24.00 & 3.75 & 32.20 & - \\
\hline \multirow{2}{*}{$\begin{array}{l}\text { RARS, } \\
\text { Jamalpur }\end{array}$} & \multirow{2}{*}{$\begin{array}{c}\text { BARI } \\
\text { Begun-8 }\end{array}$} & Treated & 1.5 & 1.50 & 43.10 & 21.81 \\
\hline & & Control & 11.0 & 3.50 & 33.70 & - \\
\hline
\end{tabular}

Validation of the developed technology: Higher bacterial disease incidence ranging from 7.50-24.00\% was observed in the control plot while it ranged from $0.88-4.50 \%$ in the treated plots of Gazipur, Jamalpur and Hathazari locations (Table 4). Root knot nematode disease severity recorded as the gall index value was also lower range dfrom 1.40-1.50 in the treated plot and higher 2.75 to 3.75 in the control plots. Integrated management package gave higher yield 43.10 to $44.50 \mathrm{t} \mathrm{ha}^{1}$ of brinjal where the yield was lower 32.20 to $33.70 \mathrm{t} \mathrm{ha}^{1}$ in the control plots. At RARS Hathazari, Chattagram yield was $25.98 \%$ higher in the treated plot compared control plot. While at Gazipur and Jamalpur the yield was 25.62\% and $21.81 \%$, respectively higher in the treated plot compared to control plot. At RARS, Jashore, bacterial wilt incidence was $22.06 \%$ and the gall index value was 3.00 producing the yield of $36.50 \mathrm{tha}^{1}$ (Table-5). In Rangpur region, no bacterial wilt disease was observed at RARS, Burirhat farm and farmers field at Gangachara, Rangpur but at OFRD, Alamnagar, Rangpur farm only 5\% bacterial wilt incidence was recorded (Table 5). The root knot disease severity was lower (1.8) at RARS, Burirhat, Rangpur but OFRD farm of Rangpur and farmers field at Gangachara, Rangpur the gall index value was higher with 2.25 and 3.25, respectively. The crop yield was higher in the OFRD, Alamnagar, Rangpur farm at $45.60 \mathrm{t} \mathrm{ha}^{1}$ where it was 44.46 and $37.13 \mathrm{t} \mathrm{ha}^{1}$ at the RARS, Burirhat and farmers field at Gangachara, Rangpur, respectively. 
Table 5. Validation of integrated management of bacterial wilt and root knot nematode of brinjal at Rangpur and Jeshore regions

\begin{tabular}{|c|c|c|c|c|}
\hline \multirow[b]{2}{*}{ Location } & \multirow[b]{2}{*}{ Variety } & \multicolumn{2}{|c|}{ Disease incidence } & \multirow[b]{2}{*}{ Yield (t/ha) } \\
\hline & & $\begin{array}{l}\text { Bacterial } \\
\text { wilt }(\%)\end{array}$ & $\begin{array}{c}\text { Root knot } \\
(\mathbf{0}-\mathbf{1 0} \\
\text { scale })\end{array}$ & \\
\hline ARS, Burirhat, Rangpur & BARI Begun-4 & 0 & 1.8 & 44.46 \\
\hline $\begin{array}{l}\text { Anil Chandra Mohanto, } \\
\text { Gangachara, Rangpur }\end{array}$ & BARI Begun-10 & 0 & 3.25 & 37.13 \\
\hline $\begin{array}{l}\text { OFRD, BARI, Alamnagar, } \\
\text { Rangpur }\end{array}$ & BARI Begun-10 & 5 & 2.25 & 45.60 \\
\hline RARS, Jeshore & BARI Begun-8 & 22.06 & 3.00 & 36.50 \\
\hline
\end{tabular}

Bacterial wilt, caused by $R$. solanacearum and root knot nematode caused by Meloidogyne spp. are the major constraints for vegetables production all over the world (Hayward, 2005; Sakhuja and Jain, 2001). These diseases are particularly important for cultivation of Solanaceous crops in tropical and subtropical climates where high temperatures and abundant rainfall during the growing season promote the disease development and dissemination. Organic amendments like poultry manure, waste materials, organic compost etc. have been recognized for soil borne diseases management and improvement of soil health (Hasan et al., 2010; Farahat et al., 2010). Results of the present study showed that integration of poultry refuse, stable bleaching powder and Furadan 5G drastically reduced bacterial wilt and root-knot disease incidence and increased plant growth parameters as well as yield of brinjal compared to control. These results were supported by Orisajo et al. (2007) and Djeugap et al. (2014) who reported that poultry manure had a suppressive effect on root-knot nematodes and bacterial wilt incidence. Biswas and Singh (2008) and Kishun (1981) reported that bleaching powder as effective in decreasing bacterial wilt. Chen et al. (2000) reported that use of organic amendments in the form of manure and compost could effectively decrease parasitic nematode populations and disease intensity on plants. The nematicidal effects of organic amendments had been attributed to several factors including increase in facultative parasites due to their richness in organic matter and release of toxic substances during decomposition (Oka, 2010; Sikora et al., 2007; Oka et al., 2007). Farahat et al. (2010) also reported that efficacy of poultry manure against plant-parasitic nematodes might either be due to stimulation of specific micro-organisms that were capable of parasitizing eggs and juveniles or production of substances from decomposition of the manure which were toxic to the nematodes. Similar studies were also done by Hassan et al. (2010) and Orisajo et al. (2007) who showed that amending the soil with organic waste materials such as poultry refuse, rice husk and saw dust suppressed the populations of Meloidogyne spp. both in the soil and roots of tomato with simultaneous increase in the growth and yield. Oka et al. 
(2007) and Orisajo et al. (2008) also reported that application of soil organic amendments was not only beneficial to nematode management but also to plant growth and productivity. Therefore, it might be concluded that integration of poultry refuse with Furadan $5 \mathrm{G}$ and stable bleaching powder was the best treatment combination for reducing root knot nematode and bacterial wilt diseases and increasing plant growth as well as yield of brinjal.

\section{References}

Ali, M. 1993. Workshop on Research and Development of vegetable crops. 9-10 March. 9-10, Institute of Post graduate Studies in Agriculture (IPSA), Gazipur-1703. pp 6875.

Bari, M. A., M. I. Faruk, M. L. Rahman and M. R. Ali. 2004. Effect of organic soil amendments and nematicide on root-knot nematode of brinjal. Bangladesh J. Plant Pathol. 20 (1\&2): 27-30.

BBS. 2005. Year Book of Agricultural Statistics of Bangladesh. Statistics Division, Bangladesh Bureu of Statistics (Monthly Statistical Bulletin, Bangladesh, December 2003). Ministry of Planning, Government of the peoples Republic of Bangladesh. 55 p.

Biswas, S. and N. P. Singh. 2008. Integrated management of wilt of tomato caused by Ralstonia solanacearum. J. Mycol. Plant Pathol. 38(2): 182-184.

Bose, T. K. and M. G. Som. 1986. Vegetable crops in India. 1st Edn. Naya Prakash. Kalkata. Pp. 262-264.

Chen, J., G. S. Abawi and B. M. Zuckerman. 2000. Efficacy of Bacillus thuringiensis, Paecilomyces marquandii and Streptomyces constaricanus with and without organic amendment against Meloidogyne hapla infecting lettuce. J. Nematol. 32: 70-77.

Das, G. P., S. Ramaswamy and M. A. Bari. 2000. Integrated crop management practices for the control of the brinjal shoot and fruit borer in Bangladesh. DAE-DANIDA Strengthening Plant Protection Services (SPPS) Project. Dept. of Agril. Extension. Khamarbari, Dhaka. 12pp.

Djeugap, J.F., D. Eko, J. Julienne, T.N. Columbus and A.D. Fonte. 2014. Effect of organic amendments and fungicide application on potato late blight, bacterial wilt and yield in Cameroon. Int. J. Agro. Agric. Res. 5 (4): 12-19.

FAOSTAT.2012. Food and Agriculture Organization of United Nations statistical database. http://faostat.fao.org/.

Farahat, A.A., A.A. Al-Sayed and N.A. Mahfoud. 2010. Compost and other organic and inorganic fertilizers in the scope of the root-knot nematode reproduction and control of Meloidogyne incognita infecting tomato. Egyptian. J. of Agronematology. 9: 18-29.

Faruk, M. I., M. A. Bari, M. S. Nahar, M. A. Rahman and M. M. Hossain. 2001. Management of root knot nematode (Meloidogyne) of tomato with two organic amendments and a nematicide. Bangladesh J. Plant Pathol. 17(1\&2): 27-30.

Hassan, M. A., P. S. Chindo, P. S. Marley and M. D. Alegbejo. 2010. Management of Root Knot Nematodes (Meloidogyne spp.) on Tomato (Lycopersicon lycopersicum) Using Organic Wastes in Zaria, Nigeria. Plant Prot. Sci.. 46 (1): 34-38. 
Hayward, A. C. 2005. Research on bacterial wilt: A perspective on international linkages and access to the literature. Pages 1-8 in: Bacterial Wilt Disease and the Ralstonia solanacearum Species Complex. C.Allen, P. Prior, and A. C. Hayward, eds. The American Phytopathol. Soc., St. Paul, MN.

Hossain, S., I. H. Mian and K. Tsuno. 1989. Efficacy of three nematicides and two oilcakes for control of root knot nematode (Meloidogyne incognita) in potato seedlings. J. Fac. Agric. Kyushu University 34(1\&2): 115-121.

Khan, A. A., K. Badshah and M. W. Khan. 1998. Resistance of aubergine cultivars to root-knot nematodes. Tests-of-Agrochemicals-and-Cultivars. 19: 40-41.

Kishun, R. 1981. Studies on bacterial wilt of solanaceous crops. Ann. Sci. Rept. IIHR, Bangalore. 18-22.

Lamovšek, J., G. Urek and S. Trdan. 2013. Biological Control of Root-Knot Nematodes (Meloidogyne spp.): Microbes against the Pests. Acta agriculturae Slovenica, $263-$ 275.

Mian, M. I. 1986. Plant parasitic nematode associated with some crop species in Bangladesh. Bangladesh J. Plant Pathol. 2(1): 7-13.

Moraes, S. R. G., V. P. Campos, E. A. Pozza, A. Fontanetti, G. J. Carvalho and C. Maximiniano. 2006. Influência de leguminosas no controle de fitonematoides no cultivo orgânico de alface americana e de repolho. Fitopatologia Brasileira 31: 188191.

Oka, Y. 2010. Mechanisms of nematode suppression by organic soil amendments - A review. Applied Soil Ecology 44: 101-115.

Oka, Y., N.Tkachi, S. Shuker and U. Yermiyahu. 2007. Enhanced nematicidal activity of organic and inorganic ammonia-releasing amendments by Azadirachta indica extracts. J. Nematiol. 39: 9-16.

Orisajo, S. B., M. O. Okeniyi, O. A. Fademi and L. N. Dongo. 2007. Nematicidal effects of water leaf extracts of Acalypha ciliata, Jatropha gossypi folia, Azadirachta indica and Allium ascalonicum on Meloidogyne incognita infection on cacao seedlings. $J$. Res. in Bioscience 3 (3): 49-53.

Orisajo, S. B., S.O. Afolami, O. Fademi and J. J. Atungwu. 2008. Effects of poultry litter and carbofuran soil amendments on Meloidogyne incognita attacks on cacao. $J$. Appl. Biosciences, 7: $214-221$.

Rahman, M. A. and M. O. Haque. 1986. Screening of tomato varieties/lines against bacterial wilt. Bangladesh J. Plant Pathol. 2(1): 15-18.

Rahman, M.F., M. R. Islam, T. Rahman and M. B. Meah. 2010. Biochemical characterisation of Ralstonia solanacerum causing bacterial wilt in brinjal in Bangladesh J. Pro. Agric. 21(1 \&2): 25-29.

Rashid, M. M. 2000. A Guidebook of Plant Pathology. Dept. of Plant Pathology. HSTU. Dinajpur. 58pp.

Sakhuja, P. K and Jain, R. K. 2001. Nematode diseases of vegetable crops and their management. In: T. S. Thind (ed.). Diseases of Fruits and Vegetables and their Management. Kalayani Pub., Ludhiana and New Delhi. pp. 439-459. 
Santana, S. M., C. R. Dias-Arieira, F. Biela, T. P. L. Cunha, F. M. Chiamolera, M. Roldi and V. H. F. Abe. 2012. Antagonistic plants in the management of Meloidogyne incognita in sandy soil of vegetables growing areas. Nematropica 42: 287-294.

Sikora, R. A., K. Schäfer and A. A. Dababat. 2007. Modes of action associated with microbially induce in planta suppression of plant-para

Sood, A. K., C. S. Kalka and A. Parashar. 1998. Eco-friendly methods for the management of bacterial wilt of tomato caused by Rolstonia solanacearum. ACIAR Bacterial Wilt Newsletter 15, 17.

Strange, R. N. and R. R. Scott. 2005. Plant disease: a threat to global food security. Annu. Rev. Phytopathol. 43: 83-116.

Viaene, N.M. and G.S. Abawi. 2000. Hirsutella rhossiliensis and Verticillium hlamydosporium as biocontrol agents of the root-knot nematode Meloidogyne hapla on Lettuce. J. Nematol. 32 (1): 85-100.

Yadessa, G.B., A. H. C. Braggen and F.L. Ocho. 2010.. Effects of different soil amendments on bacterial wilt caused by Ralstonia solanacearum and on the yield of tomato. J. Plant Pathol. 92(2): 439-450

Zakaria, H. M., A.S. Kassab, M.M. Shamseldean, Mona M. Oraby and M.M.F. ElMourshedy. 2013. Controlling the root-knot nematode, Meloidogyne incognita in cucumber plants using some soil bioagents and some amendments under simulated field conditions. Ann. Agric. Sci. 58(1): 77-82

Zeck, M. W., 1971. A rating scheme for field evaluation of root knot nematode infestation. Planzenschuta-Nacht, 24: 141-144. 
